\title{
OCENA BÓLU U CHORYCH Z PRZEWLEKŁYM NIEDOKRWIENIEM KOŃCZYN DOLNYCH
}

\author{
EVALUATION OF PAIN IN PATIENTS WITH CHRONIC LIMB ISCHEMIA \\ Beata Skokowska ${ }^{1, a}$, Katarzyna Topolska-Małecka², Anna Bielawska ${ }^{1, b}$, Grażyna Bączyk ${ }^{1, c}$ \\ ${ }^{1}$ Zakład Praktyki Pielęgniarskiej, Katedra Pielęgniarstwa, Wydział Nauk o Zdrowiu, \\ Uniwersytet Medyczny im. Karola Marcinkowskiego w Poznaniu \\ ${ }^{2}$ Oddział Chirurgii Ogólnej i Naczyń, Szpital Kliniczny im. Przemienienia Pańskiego w Poznaniu \\ ${ }^{a}$ https://orcid.org/0000-0001-9844-9903 \\ ${ }^{\mathrm{b}} \mathrm{https}: / /$ orcid.org/0000-0001-9903-4857 \\ ${ }^{c}$ https://orcid.org/0000-0001-8919-5729
}

DOI: https://doi.org/10.20883/pielpol.2020.16

\section{STRESZCZENIE}

Wstęp. Choroba tętnic obwodowych (peripheral artery disease, PAD) stanowi grupę jednostek chorobowych o wspólnym podłożu związanym z rozwojem miażdżycy. Najczęstszą dolegliwością z jaką pacjenci zgłaszają się do lekarza jest ból kończyn dolnych. Odległość jaką pokonuje chory do czasu wystąpienia bólu nazywana jest dystansem chromania. W krytycznym niedokrwieniu ból kończyny pojawia się również w spoczynku, często nasila się w nocy w trakcie snu.

Cel. Celem pracy była ocena doznań bólowych u chorych z przewlekłym niedokrwieniem kończyn dolnych.

Materiał i metody. Badania prowadzono na Oddziale Chirurgii Ogólnej i Naczyniowej „D” w Szpitalu Klinicznym im. Przemienienia Pańskiego w Poznaniu. Badanie przeprowadzono z zastosowaniem Kwestionariusza do Oceny Bólu według McGill-Melzacka oraz skali numerycznej - NRS (Numerical Rating Scale). W badaniu wzięło udział 52 pacjentów (kobiet $\mathrm{n}=20,38 \%$; mężczyzn $\mathrm{n}=32 ; 62 \%$ ), w przedziale wiekowym od 52 do 82 lat.

Wyniki. Wszyscy badani zgłaszali dolegliwości bólowe kończyn dolnych; średnie natężenie bólu wynosiło 8 pkt wg skali numerycznej. Najczęściej wskazywanym miejscem bólu były mięśnie łydki. Wśród określeń bólu badani najczęściej wybierali określenia: męczący (96,15\%), uciążliwy (96,15\%), dokuczliwy $(94,23 \%)$. Wykazano zależność pomiędzy stopniem niedokrwienia według skali Fontaine'a a aktualną oceną bólu oraz liczbą wybieranych określeń bólu.

Wnioski. Dolegliwości bólowe występowały u wszystkich badanych z przewlekłym niedokrwieniem kończyn dolnych. Liczba wybieranych określeń bólu wzrastała wraz ze zmniejszaniem się dystansu chromania przestankowego. Stopień niedokrwienia kończyn dolnych miał wpływ na natężenie dolegliwości bólowych.

SŁOWA KLUCZOWE: choroba tętnic obwodowych PAD, przewlekłe niedokrwienie kończyn dolnych, ból.

\begin{abstract}
Introduction. Peripheral artery disease (PAD) is a group of disease entities with a common background associated with the development of atherosclerosis. The most common complaint reported to the doctor by patients is pain in the lower limbs. The distance covered by the patient until the onset of pain is called intermittent claudication. In critical ischemia, limb pain also occurs at rest, often worsens at night during sleep.

Aim. The objective of the study was to assess pain sensation in patients with chronic ischaemia of the lower limb.

Material and methods. The study was conducted at the General and Vascular Surgery Department "D" of the Clinical University Hospital of Lord's Transfiguration in Poznan. The study was conducted using the McGill-Melzack Pain Questionnaire and the Numerical Rating Scale (NRS). The study involved 52 patients (women $n=20,38 \%$; men $n=32,62 \%$ ) in the age range from 52 to 82 years.

Results. All study participants reported pain of the lower limbs; the mean pain intensity was 8 points according to the Numerical Scale. The most frequently mentioned pain areas were calf muscles. The most often chosen pain descriptions were: tiresome (96.15\%), oppressive (96.15\%), nagging (94.23\%). Authors found the relationship between the degree of ischaemia according to the Fontaine classification and the current pain assessment and the number of selected descriptions of pain.

Conclusions. Pain occurred in all subjects with chronic lower limb ischemia. The number of pain descriptions chosen increased with the decrease of the intermittent claudication distance. The degree of ischemia of the lower limbs influenced the intensity of pain.
\end{abstract}

KEYWORDS: peripheral artery disease PAD, chronic ischemia of lower limbs, pain. 


\section{Wprowadzenie}

Miażdżyca jako choroba przewlekła, rozwijająca się wskutek odkładania produktów metabolicznych na wewnętrznych ścianach tętnic, prowadzi do zmniejszenia przepływu krwi w tkankach, a to z kolei do niewystarczającego ich utlenowania. Staje się to powodem dysfunkcji niedostatecznie ukrwionych narządów i kończyn. Choroba tętnic obwodowych (ang. peripheral artery disease, PAD) stanowi grupe jednostek chorobowych o wspólnym podłożu związanym z rozwojem miażdżycy, ale różnych objawach i przebiegu. Na podstawie lokalizacji wyróżnia się: chorobę tętnic kręgowych, tętnic kończyn górnych, tętnic szyjnych, tętnic nerkowych, tętnic kończyn dolnych oraz chorobę tętnic krezkowych [1]. PAD występująca w obrębie tętnic kończyn dolnych (ang. lower extremities coronary artery diseases, LEAD) dotyczy przede wszystkim pacjentów w wieku powyżej 50 lat, a częstość występowania zwiększa się wraz z wiekiem; została oceniona w kilku badaniach epidemiologicznych na obiektywnych testach i wynosi od $3 \%$ do $10 \%$, zwiększając się do $15 \%$ - 20\% u osób w wieku powyżej 70 lat [2]. W ostatnich latach częstość występowania LEAD się zwiększa i, co bardzo niepokojące, choroba dotyka coraz młodsze osoby [3]. PAD jest po chorobie wieńcowej i udarze trzecią najczęstszą przyczyną chorób układu sercowo-naczyniowego. Dodatkowo stwierdza się tendencję wzrostową liczby osób z chorobą tętnic obwodowych. Współczynnik śmiertelności wśród chorych z krytycznym niedokrwieniem kończyn dolnych wynosi $20 \%$ w ciągu 6 miesięcy od rozpoznania i $50 \%$ w ciągu 5 lat [2].

Współczesne zasady diagnozowania i leczenia miażdżycowego niedokrwienia kończyn dolnych opierają się głównie na wytycznych TransAtlantic InterSociety Consensus (TASC II) obejmujących zalecenia dotyczące rodzaju wykonywanych badań i sposobów leczenia w wybranych postaciach klinicznych miażdżycy tętnic kończyn dolnych [3-4].

Niedokrwienie kończyn dolnych objawia się wieloma dolegliwościami, które z czasem coraz bardziej utrudniają pacjentowi sprawne funkcjonowanie. W literaturze wyróżnia się takie objawy, jak uczucie mrowienia, drętwienia, chromanie przestankowe, parestezje, osłabienie siły mięśniowej, owrzodzenia, utrudnione gojenie się ran czy w krytycznych przypadkach martwicę tkanek. Najczęstszą dolegliwością, z jaką pacjenci zgłaszają się do lekarza, jest ból przewlekły kończyn dolnych. Nasilenie, czas trwania, charakter, sposób w jaki chory radzi sobie z bólem są bardzo ważnymi wskaźnikami rozpoznania. Objawy choroby uzależnione są głównie od umiejscowienia zwężenia oraz stopnia, w jakim rozwinęło się krążenie oboczne. Głównym objawem nie- dokrwienia kończyn dolnych jest chromanie przestankowe - ból mięśni kończyny o natężeniu zmuszającym chorego do zatrzymania, wywołany chodzeniem i ustępujący podczas przerwy. Ból powraca przy kontynuacji marszu, po pokonaniu odcinka o podobnej odległości [5], który zmusza chorego do zatrzymania się. Po chwili odpoczynku chory idzie dalej i cała sytuacja się powtarza. Ów określony i stały, lecz dla każdego chorego inny odcinek, nazywa się dystansem chromania [6].

W krytycznym niedokrwieniu kończyn ból pojawia się również w spoczynku, w nocy, przy płaskim ułożeniu kończyny. Ustępuje natomiast po opuszczeniu kończyn i dlatego pacjenci często śpią na siedząco lub leżąco ze spuszczonymi nogami. W późniejszym okresie choroby nawet opuszczenie kończyn dolnych i zastosowanie silnych leków p/bólowych nie przynosi ulgi, co skutkuje wyczerpaniem zarówno fizycznym, jak i psychicznym [7-11].

\section{Cel pracy}

Celem pracy była ocena doznań bólowych u chorych z przewlekłym niedokrwieniem kończyn dolnych.

\section{Materiał i metody}

Badaniem objęto 52 chorych: 20 kobiet (38\%) i 32 mężczyzn (62\%), w wieku 52-82 lata, hospitalizowanych na Oddziale Chirurgii Ogólnej i Naczyń „D” w Szpitalu Klinicznym im. Przemienienia Pańskiego w Poznaniu. Udział w badaniu był dobrowolny i anonimowy. $\mathrm{Na}$ przeprowadzenie badań uzyskano zgodę Dyrekcji Szpitala, Kierownika Oddziału oraz Komisji Bioetycznej przy Uniwersytecie Medycznym im. Karola Marcinkowskiego w Poznaniu (uchwała nr 409/16).

U każdego pacjenta oceniono rodzaj dolegliwości bólowych i stopień ich nasilenia przy użyciu najnowszej wersji Kwestionariusza do Oceny Bólu według McGill-Melzacka oraz skali numerycznej. Kwestionariusz ten umożliwia dokładne ilościowe i jakościowe określenie poziomu bólu. Składa się z: 78 przymiotników/cech określających ból, rysunku wskazującego jego umiejscowienie oraz sześciostopniowej skali określającej aktualną intensywność bólu - AIB (od 0 do 5, gdzie „0” oznacza brak bólu, a „5” - ból nie do wytrzymania). Określenia bólu zawarte w kwestionariuszu tworzą cztery kategorie, które łącznie zawierają 20 grup. Pierwsza kategoria opisuje sensoryczne właściwości bólu (grupy 1-10), druga dotyczy cech emocjonalnych (grupy 11-15), trzecia - grupa 16 - odnosi się do ogólnej oceny bólu jako doznania subiektywnego) i czwarta jako grupa kontrolna opisuje sensoryczne i emocjonalne właściwości bólu (grupy 17-20) [12-14]. 
Do oceny pomiaru intensywności bólu zastosowano skalę numeryczną NRS (Numerical Rating Scale), która zawiera 11 stopni nasilenia bólu: od 0 do 10, gdzie „0” oznacza brak bólu, natomiast „10” najgorszy wyobrażalny ból. Badani byli pytani o stopień bólu, który zmuszał ich do zatrzymania się podczas chodzenia.

\section{Analiza statystyczna}

Przy ocenie zależności zmiennych w skali porządkowej użyto współczynnika korelacji rangowej R Spearmana. Do obliczenia różnic średnich między grupami niezależnymi użyto testu U Manna-Whitneya. Jako poziom istotności przyjęto $p<0,05$.

Dane uzyskane w badaniu poddano analizie statystycznej z użyciem programu SPSS 20.

\section{Wyniki}

Grupę badaną stanowiło 52 pacjentów: 20 kobiet (38\%) i 32 mężczyzn (62\%) w przedziale wiekowym od 52 do 82 lat. Średnia wieku badanych wynosiła 66 lat (kobiety 66,9 lat, mężczyźni 65,9 lat).

Stopień niedokrwienia kończyn dolnych został określony wg IV-stopniowej klasyfikacji Fontaine'a. Najliczniejszą, 19-osobową grupę (36,54\%) stanowili chorzy ze stopniem II B (chromanie przestankowe - dystans < $200 \mathrm{~m}$ ), na drugim miejscu $16(30,76 \%)$ chorych ze stopniem III (ból spoczynkowy) i 13 (25\%) pacjentów ze stopniem IV (owrzodzenia i martwica). Ostatecznie 4 (7,7\%) chorych posiadało stopnień I (bezobjawowy, objawy niespecyficzne, drętwienia) i II A (chromanie przestankowe - dystans > $200 \mathrm{~m}$ ).

Analiza odległości, jaką badani byli w stanie przejść do momentu pojawienia się bólu (chromania przestankowego), wykazała, że maksymalny dystans wyniósł $800 \mathrm{~m}(\mathrm{n}=1)$, natomiast minimalny $5 \mathrm{~m}-10(19,23 \%)$ badanych (Rycina 1).

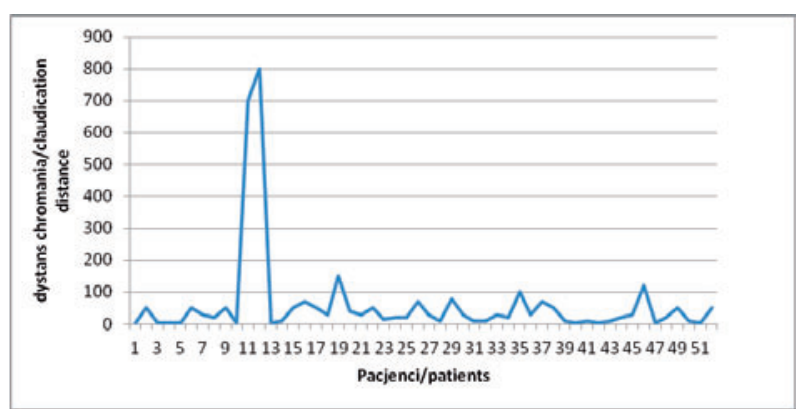

Rycina 1. Dystans chromania przestankowego Figure 1. Distance of intermittent claudication

Źródło: opracowanie własne

Source: author's own analysis

\section{Ocena bólu według skali NRS}

Badani za pomocą skali NRS wskazywali na ból, który zmuszał ich do zatrzymania się i odpoczynku. Analiza natężenia bólu wykazała, że żaden badany nie odnotował bólu na niskim poziomie (od 0 pkt. do 5 pkt.). Ból na wyższym poziomie odnotowało: 7 poziom - $11(21,2 \%)$ chorych, 8 - 16 (30,8\%), 9 - 14 (26,9\%) i $10-5(9,6 \%)$ badanych.

Podczas oceny bólu chorzy podawali również miejsce jego występowania. Najczęściej wskazywanym miejscem była łydka - 37 (71\%) chorych. Pozostała grupa badanych wskazywała na dolegliwości łydki i uda - 14 (26,9\%). Najmniej, 3 (6\%) badanych podawało dolegliwości bólowe biodra. Miejscem wskazywania bólu przez 3 (6\%) chorych była tylko stopa. Znaczna grupa badanych w trakcie oceny bólu podawała występowanie dolegliwości w kilku obszarach.

\section{Analiza określeń bólu}

Analizując wyniki uzyskane z wykorzystaniem Kwestionariusza do oceny bólu według McGill-Melzacka, zsumowano liczbę wybranych słów (Number of Selected Words, LWS) dla każdego pacjenta. Średnio wybierano 24 określenia bólu.

W kategorii I (cechy sensoryczne) najczęściej wybieranymi określeniami charakteru bólu były: piekący - 28 (54\%), dźgający - 23 (44\%), mrowiący - 22 (42\%), ściskający - 21 (40\%), swędzący - 18 (35\%), migający - 17 (33\%), spinający - 16 (31\%), gorący - 14 (27\%), pulsujący, świdrujący - 26 (25\%).

Według kategorii II (cechy emocjonalne) na ból męczący uskarżało się - 50 (96\%) badanych, na dręczący - 44 (85\%), nękający - 41 (79\%), straszny - 26 (50\%), niesamowity - 23 (44\%) i nużący - 18 (35\%). W tej kategorii nie wybrano określeń: zabójczy i oślepiający.

Kategoria III pozwala na ogólną ocenę bólu jako doznania subiektywnego. Zdecydowana większość badanych opisało ból jako uciążliwy - 50 (96\%), nieprzyjemny - 46 (88\%), przykry - 41 (79\%), okropny - 34 (65\%) i nie do zniesienia - 24 (46\%).

Kategoria IV, jako grupa kontrolna, opisuje sensoryczne i emocjonalne właściwości bólu. Prawie wszyscy badani - 49 (95\%) przyznali, że ból jest dokuczliwy, nieznośny - 39 (75\%), odrętwiający - 37 (71\%), napinający i promieniujący - 31 (60\%). Bólu wstrętnego i ciągnącego doznała połowa respondentów.

W dalszej kolejności badani oceniali okresowość dolegliwości bólowych. Najczęściej powtarzało się określenie: ból przejściowy - 34 (65\%) i przerywany 27 (52\%). Równie duża grupa wskazała na chwilowy i ciągły charakter bólu (25; $48 \%$ vs $24 ; 46 \%)$. Określenie „ból ciągły” w 95,8\% było wskazane przez pacjentów 
z 3 i 4 stopniem niedokrwienia kończyn dolnych wg klasyfikacji Fontaine'a.

Dokonując pomiaru aktualnej intensywności bólu (AIB) wg 6-stopniowej skali, stwierdzono, że dolegliwości bólowe zgłaszało 33 (63,5\%) chorych i że są one na różnym poziomie. Najliczniejsze grupy oceniły je na 3 i 2 pkt. (11; 21\% vs 9; 17,5\%), na ból o intensywności 1 i 4 pkt. uskarżało się łącznie 23\% pacjentów (6; 11,5\% vs $6 ; 11,5 \%$ ), najsilniejszy ból na poziomie 5 pkt. zgłaszał 1 (2\%) badany.

Analiza korelacji nie wykazała znaczących statystycznie zależności pomiędzy poziomem natężenia bólu a zmiennymi demograficznymi, takimi jak wiek, płeć ( $p>0,05)$.

Nie wykazano również znaczącej statystycznie korelacji pomiędzy sumą wybranych określeń bólu (LWS) a płcią $(p>0,05)$.

Występowała znacząca statystycznie ujemna korelacja pomiędzy dystansem chromania przestankowego a liczbą wybranych określeń bólu $(r=-0,367 ; p<0,01)$. Chorzy, którzy pokonywali krótszy dystans bez bólu, wybierali więcej określeń bólu.

Wykazano również znaczącą statystycznie korelację pomiędzy liczbą wybranych określeń bólu a stopniem niedokrwienia kończyn dolnych wg skali Fontaine'a. Obserwowano dodatnią korelację $(r=0,335$; $p<0,05)$, co oznacza, że badani z większym stopniem niedokrwienia kończyn wybierali więcej słów charakteryzujących ich doznania bólowe (Rycina 2).

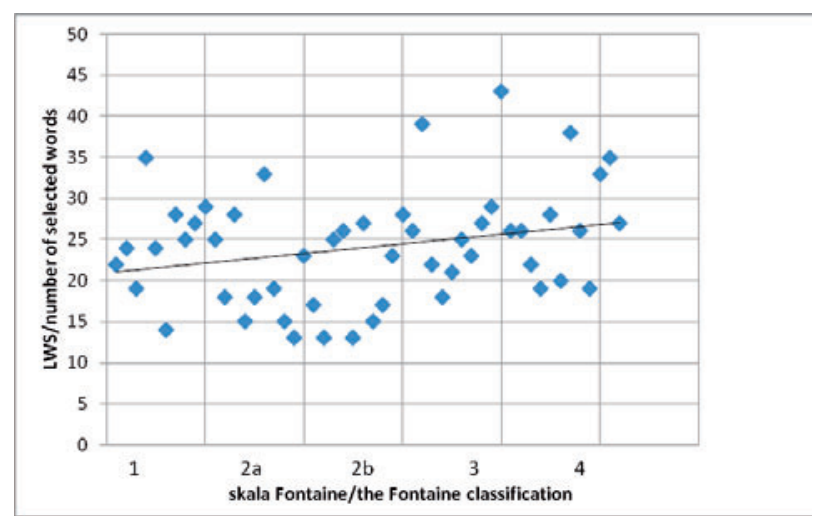

Rycina 2. Korelacja pomiędzy liczbą wybranych słów w skali LWS i stopniem niedokrwienia kończyn wg skali Fontaine'a

Figure 2. Correlation between the number of selected words on the LWS scale and the degree limb ischemia according to the Fontaine scale

Źródło: opracowanie własne

Source: author's own analysis

Stwierdzono również silną dodatnią korelację pomiędzy stopniem niedokrwienia kończyn dolnych w skali Fontaine'a a aktualną oceną bólu. Oznacza to, że chorzy ze znacznie większym niedokrwieniem kończyn odczuwali silniejszy ból $(r=0,795 ; p<0,001)$.

\section{Dyskusja}

Miażdżyca to postępująca, przewlekła choroba naczyń o wieloczynnikowym podłożu powodująca upośledzenie sprawności śródbłonka. Zmiany w tętnicach spowodowane zwłóknieniem pewnego odcinka lub całej długości tętnicy przyczyniają się do jej zwężenia, a w konsekwencji do całkowitego zamknięcia światła. Jednym z pierwszych objawów są bóle kończyn dolnych, odczuwane podczas chodzenia, zmuszające chorego do zatrzymania się i odpoczynku. Odległość, jaką chory może przejść do momentu wystąpienia bólu, nazywana jest dystansem chromania przestankowego. Rozwój choroby skraca dystans, jaki chory może pokonać, a ból staje się bardzo silny i uciążliwy, pacjent odczuwa go nawet w spoczynku [7-8, 15-16]. Rozwój społeczny i związane z tym wydłużenie długości życia wiąże się nieodzownie z częstszym występowaniem PAD czy LEAD w obrębie tętnic kończyn dolnych. W codziennej praktyce klinicznej wpływa to istotnie na zwiększenie zapotrzebowania na opiekę w grupie osób obciążonych schorzeniem i jego następstwami (w zakresie sprawności funkcjonalnej, radzenia z bólem, problemów ze snem oraz stosunków rodzinnych i reakcji emocjonalnych). Szacuje się, że więcej niż co 5. chory, u którego występują znaczne objawy chromania przestankowego, umrze w ciągu najbliższych 5 lat, a u kolejnych $20 \%$ wystąpi niekorzystny incydent sercowo-naczyniowy, taki jak udar mózgu czy zawał serca [3, 17].

W naszych badaniach większość grupy (62\%) stanowili mężczyźni, 38\% badanych stanowiły kobiety. Średnia wieku dla ogółu badanych wynosiła 66 lat. Norgren i wsp. [3] donoszą, iż u pacjentów z chromaniem przestankowym stosunek mężczyzn do kobiet wynosi od 1:1 do 2:1. W niektórych badaniach stosunek ten wzrasta do 3:1 w bardziej zaawansowanych stadiach choroby. W badaniach Ponczek i wsp. [18] dominującą grupę stanowili mężczyźni 69,5\%, kobiety tylko 30,5\%. Jednakże, aż dla 88,1\% badanych średnia wieku była powyżej 51. roku życia. Również w badaniach Wiśniewskiej i wsp. [19] dominującą grupę (w wieku 52-83 lata) stanowili mężczyźni - 78\%. Badania potwierdzają, iż choroby naczyniowe nasilają się u osób płci męskiej oraz powyżej 50. roku życia.

Ból często jest źródłem cierpienia i obniżenia jakości życia. Ma on wpływ zarówno na fizyczną, psychiczną, jak i społeczną sferę życia [20]. Wielowymiarowa ocena stanu zdrowia, jak i nowoczesne standardy postępowania w codziennej praktyce klinicznej zakładają indywi- 
dualizację terapii nad pacjentem przy jego współudziale w planowaniu terapii, celem poprawy jakości życia [20-21].

W naszych badaniach nasilenie dolegliwości bólowych oceniono m.in. w skali NRS; zakres punktacji wynosił od 0 do 10. Chorzy określili ból, który występuje podczas chodzenia i zmusza ich do odpoczynku. Średnia ocena bólu wynosiła 8 pkt. Nikt z badanych nie określił poziomu bólu jako niski i średni, poniżej 6 pkt. $10 \%$ badanych oceniło ból na 10 pkt. i byli to głównie chorzy z IV stopniem niedokrwienia. Ocena bólu nie była uzależniona od wieku i płci. Pacjenci z III i IV stopniem niedokrwienia opisywali częstotliwość występowania bólu jako ciągły (95,8\% osób), pozostali najczęściej odpowiadali, że ból jednocześnie jest przerywany, okresowy, przejściowy i krótkotrwały. Autorzy poprosili również badanych o ocenę aktualnej intensywności bólu (AIB) w skali od 0 do 5 . Znaczna grupa pacjentów (63\%) uskarżała się na odczucie bólu i związany z nim dyskomfort. Jedynie 37\% badanych osób deklarowało brak dolegliwości bólowych. Szeroki ,język dolegliwości bólowych" świadczy o tym, że ból jest cechą zmienną i indywidualną dla każdego pacjenta.

Porównując dolegliwości bólowe, oceniane w skali NRS w badaniach Białasik i wsp. [22] u pacjentów z owrzodzeniem kończyn dolnych, wykazano, że połowa badanych odczuwała ból na poziomie $0-5$, a pozostali na poziomie 5-7 pkt. Pacjenci, którzy uskarżali się na ból stały, oceniali go na 5 pkt. (40\%), natomiast chorzy uskarżający się na ból okresowy opisywali dolegliwości bólowe na poziomie 7 i 8 pkt.

W badaniach Wiśniewskiej i wsp. [19] określano natężenie bólu spoczynkowego u chorych z PAD, zakwalifikowanych do zabiegu rewaskularyzacji, przy użyciu skali numerycznej. Średnia wartość natężenia bólu wynosiła 5,89 pkt. Jednak część badanych natężenie bólu oceniła na poziomie silnych dolegliwości, a 11,1\% chorych opisało ból w kategoriach maksymalnych.

W naszych badaniach nie wykazano korelacji pomiędzy natężeniem bólu a zmiennymi demograficznymi, takimi jak wiek, płeć. Badania przeprowadzone przez Wiśniewską i wsp. [19] również nie potwierdziły zależności stopnia nasilenia bólu od płci i wieku.

Zaskakującym jest doniesienie opublikowane przez Norgren i wsp. [3], iż klasyczny objaw, jakim jest chromanie przestankowe, nie zawsze jednoznacznie świadczy o PAD. Należy pamiętać, że niektórzy pacjenci prezentujący objawy podobne do chromania przestankowego mogą nie mieć PAD (np. ucisk rdzenia może powodować objawy podobne do chromania przestankowego przy braku zmian w naczyniach krwionośnych). Z drugiej strony u części osób z zaawansowaną PAD może nie występować chromanie przestankowe, z uwagi na istnienie czynników ograniczających aktywność, jak również znaczna cześć chorych prowadzi siedzący tryb życia. Historia objawów pacjentów z miażdżycą kończyn dolnych, prezentowana w „Konsensus postępowania w chorobie tętnic obwodowych (TASC II)", potwierdza, iż nie wszystkie objawy zgłaszane przez chorych są charakterystyczne dla PAD. Typowe chromanie przestankowe to $10-35 \%$ populacji pacjentów z PAD w wieku 50 i więcej lat. Inny ból kończyny dolnej zgłasza 30-40\% populacji pacjentów z PAD [3]. W badaniach własnych część chorych zgłaszało trudności z lokalizacją dolegliwości bólowych bądź ich nietypową lokalizację, np. w obrębie stopy. Wytyczne TransAtlantic InterSociety Consensus (TASC II) w zakresie diagnozowania miażdżycowego niedokrwienia kończyn dolnych zawierają zasady diagnostyki różnicowej chromania przestankowego. Autorzy podają, iż możemy ocenić chromanie stopy, które charakteryzuje się jako ciężki ból podczas wysiłku zlokalizowany w łuku stopy, również może występować jako drętwienie [3].

Ponczek i wsp. [18], posługując się skalą oceny bólu wg Barbary Headley, odnotowali średnią ocenę bólu na poziomie 5,25 pkt. Ten wynik jest niższy, niż wynik uzyskany w badaniach własnych na poziomie 8 pkt.

Analizując wyniki otrzymane za pomocą Kwestionariusza Oceny Bólu Ronalda Melzacka, uzyskano informacje na temat jakościowych odczuć bólowych. W kategorii cech sensorycznych, zarówno prezentowane badania własne, jak i wyniki innych badań wykazały, że blisko połowa pacjentów identyfikowała odczucie bólu jako tętniący i pulsujący. W naszych badaniach jedna trzecia chorych określała ból jako „kłujący”. Chorzy zarówno w naszych badaniach, jak i w badaniach innych autorów [1, 18, 19, 22] bardzo często używali przymiotników określających odczuwany ból jako: palący i gorący, wrzynający się i rozcinający. Jednakże odczucia te są bardzo indywidualne [23].

Z odmienności odczuć każdego pacjenta wynika, że ocena i charakterystyka bólu spowodowanego niedokrwieniem kończyn dolnych nie jest łatwym zadaniem. Pacjenci różnorodnie opisują zarówno dolegliwości bólowe, jak i stopień nasilenia bólu. Badania wykazały, że im krótszy odcinek chory jest w stanie pokonać bez bólu, tym dolegliwości bólowe są silniejsze i pacjent używa więcej słów do ich opisania. Wyniki naszych badań i publikowane przez innych autorów $[18,19,22]$ są zgodne co do identyfikacji nieprzyjemnych emocji związanych z bólem.

Istnieje jednak duża grupa osób, u których choroba przebiega bezobjawowo.

W niektórych przypadkach nawet znacznego stopnia zmiany miażdżycowe nie powodują wystąpienia dolegliwości. Inne objawy, które mogą pośrednio su- 
gerować obecność PAD to np. zaniki mięśniowe, zaniki przydatków skóry (włosy, paznokcie). U części chorych najbardziej zauważalnym objawem mogą być zaburzenia termoregulacji. Szczególnie dotyczy to chorych na cukrzycę, gdzie istotną rolę odgrywa obecność neuropatii [24].

W celu ustalenia strategii postępowania wskazane są konsultacje wielodyscyplinarnych zespołów, gdyż występowanie PAD łączy się ze znacznym wzrostem ryzyka występowania powikłań sercowo-naczyniowych. U każdego pacjenta należy pamiętać o zaleceniu modyfikacji stylu życia (m.in. bezwzględny zakaz palenia tytoniu, zdrowa dieta uboga w nasycone kwasy tłuszczowe z naciskiem na produkty pełnoziarniste, warzywa, owoce i ryby, regularna aktywność fizyczna) [1, 25]. Jawień i wsp. [26] opublikowali szczegółowe zalecenia dotyczące niefarmakologicznych interwencji prozdrowotnych pacjentów z chorobą tętnic kończyn dolnych. Zawarte są one w Polskich wytycznych postępowania w chorobie tętnic kończyn dolnych (LEAD) opracowanych na podstawie wytycznych ESVS/ESC 2017, które powinny stanowić przewodnik postępowania służący poprawie jakości życia chorych z niedokrwieniem kończyn dolnych.

\section{Wnioski}

1. Liczba określeń dolegliwości bólowych spowodowanych przewlekłym niedokrwieniem kończyn dolnych wzrasta wraz ze zmniejszaniem się dystansu chromania przestankowego.

2. Pacjenci z większym stopniem niedokrwienia kończyny odczuwają silniejsze dolegliwości bólowe.

3. Ocena nasilenia bólu wg skali numerycznej nie jest zależna od płci i wieku.

4. W opiece pielęgniarskiej wskazana jest obserwacja nie tylko nasilenia dolegliwości bólowych, ale również określeń bólu wskazywanych przez chorego.

\section{Piśmiennictwo}

1. Szymański FM. Diagnostyka i farmakoterapia pacjentów z chorobą tętnic obwodowych - o czym powinniśmy pamiętać w codziennej praktyce? Choroby Serca i Naczyń 2014; t. 11(3): 152-158.

2. Fowkes FGR, Rudan D, Rudan I, Aboyans V, Denenberg JO, McDermott MM, et al. Comparison of global estimates of prevalence and risk factors for peripheral artery disease in 2000 and 2010: a systematic review and analysis. Lancet 2013; 382: 1329-1340, DOI: https://doi.org/10.1016/S01406736(13)61249-0, [data wejścia 21.10.2019].

3. Norgren L, Hiatt WR, Dormandy JA, Nehler MR, Harris KA, Fowkes FGR. Inter-Society Consensus for the Management of Peripheral Arterial Disease (TASC II). J Vasc Surg. 2007; 45 (1sup),5-67.DOI: https://doi.org/10.1016/j. jvs.2006.12.037 [data wejścia 21.10.2019].
4. Criqui MH, Aboyans V. Epidemiology of Peripheral Artery Disease. Circ Res. 2015; 116: 1509-1526. DOI: https:// www.ahajournals.org/doi/full/10.1161/CIRCRESAHA .116.303849 [data wejścia 21.10.2019].

5. Bronas UG, Hirsch AT, Murphy T i in. Design of the multicenter standardized supervised exercise training intervention for the 'Claudication: Exercise Vs Endoluminal Revascularization (CLEVER) study'. Vasc Med. 2009; 14: 313-321.

6. Piotrkowska R, Dobosz M, Halena G, Książek J. Edukacja terapeutyczna w leczeniu chorych na miażdżycę tętnic kończyn dolnych. Piel Chir Angiol. 2011; 1: 13-17.

7. Paplaczyk M, Gawor A, Ciura G. Ocena jakości życia pacjentów z bólem przewlekłym w przebiegu choroby niedokrwiennej kończyn dolnych. Piel Chir Angiol. 2015; 3: 135-140.

8. Szmidt J, Kużdżał J. Podstawy chirurgii - tom 1-2 - podręcznik dla lekarzy specjalizujących się w chirurgii ogólnej. Med Prakt. 2009; 1181-1185, 1228-1245.

9. Noszczyk W, Andziak P. Przewlekłe niedokrwienie kończyn dolnych. W: Noszczyk W (red). Chirurgia tętnic i żył obwodowych. t. 2. Warszawa: PZWL, 2007, 562-575.

10. Myrcha P. Badanie kliniczne tętnic i żył obwodowych. W: Noszczyk W (red). Chirurgia tętnic i żył obwodowych. t. 1. Warszawa: PZWL; 2007. 125-132.

11. Uccioli L, Meloni M, Izzo V, Giurato L, Merolla S, Gandini R. Critical limb ischemia: current chalenges and future prospects. Vasc Health Risk Manag. 2018; 14: 63-74.

12. Kołłątaj M, Wordliczek J, Dobrogowski J. Kwestionariusz do Oceny Bólu McGill (McGill Pain Questionnaire, MPQ) i skrócona wersja Kwestionariusza do Oceny Bólu McGill. Ból 2013; 14, 3: 10-13.

13. Chojnacka-Kuraś M. Semantyka bólu we współczesnej polszczyźnie. Praca Doktorska. Uniwersytet Warszawski Wydział Polonistyki. Warszawa. 2013. 13-15.

14. Burckhardt CS, Jones KD. Adult measures of pain. Arthritis \& Rheumatism. Arthritis Care Res. 2003; 5: 96-104.

15. Janicki S. Choroby tętnic - rozpoznanie i leczenie. W: Zasłonka J, Jaszewski R, Janicki S (red). Wybrane zagadnienia z chirurgii serca, naczyń i klatki piersiowej. Łódź: AM; 1996. 65-83.

16. Zapolska-Downar D, Naruszewicz M. Molekularne podłoże miażdżycy. W: Noszczyk W (red). Chirurgia tętnic i żył obwodowych. t. 1. Warszawa: PZWL; 2007. 73-93.

17. Rothwell PM, Coull AJ, Silver LE i wsp. Population-based study of event-rate, incidence, case fatality, and mortality for all acute vascular events in all arterial territories (Oxford Vascular Study). Lancet 2005; 366: 1773-1783.

18. Ponczek D, Piotrowska K, Felsmann M, Humańska M. Percepcja bólu u chorych z przewlekłym niedokrwieniem kończyn dolnych. Piel Chir Angiol. 2012; 6: 13-19.

19. Wiśniewska A, Szewczyk MT, Cwajda-Białasik J, Cierzniakowska K, Jawień A. Przekonania na temat kontroli bólu u chorych z przewlekłym niedokrwieniem kończyn dolnych. Piel Chir Angiol. 2009; 3: 113-121.

20. Sękowska A, Kucia H, Malec-Milewska M. Ocena kliniczna pacjenta z bólem przewlekłym. Terapia. 2013; 6 z 2 (290): 63-66.

21. Ponczek D, Szajkowska L. Ocena przystosowania się do życia chorych z miażdżycą tętnic kończyn dolnych. Piel Chir Angiol. 2015; 2: 124-129.

22. Białasik B, Muszalik M, Szewczyk M. Ocena dolegliwości bólowych u chorych z owrzodzeniem kończyny dolnej. Piel Chir Angiol. 2007; 4: 150-157.

23. Piotrkowska R, Dobosz M, Książek J, Halena G. Jakość życia chorych z miażdżycą naczyń obwodowych - przegląd piśmiennictwa. Ann Acad Med. Gedan. 2011; 41: 89-95. 
24. Krosny T, Raciborski W, Madycki G, Staszkiewicz W. Możliwości oceny zaburzeń ukrwienia u pacjentów z przewlekłym miażdżycowym niedokrwieniem kończyn dolnych. Post Nauk Med. 2012; 3: 35-40.

25. Spannbauer A, Berwecki A, Ridan T, Mika P, Chwała M. Miażdżycowe niedokrwienie kończyn dolnych - o czym powinni wiedzieć fizjoterapeuta i pielęgniarka. Piel Chir Angiol. 2017; 11 (4): 117-127.

26. Jawień A, Filipiak KJ, Bręborowicz A et al. Polish guidelines for the management of lower extremity arterial disease (LEAD) based on ESVS/ESC 2017 guidelines. Principles of the management and care of patients with lower extremity arterial disease: position document of PTChN, PTNT, PTLR and SFSN PTK experts. Acta Angiol. 2019; 25, 4. doi: 10.5603/AA.2019.0015.
Artykuł przyjęty do redakcji: 04.06.2019.

Artykuł przyjęty do publikacji: 14.11.2019.

Źródło finansowania: brak.

Konflikt interesów: nie zadeklarowano.

Adres do korespondencji:

Beata Skokowska

ul. Smoluchowskiego 11

60-205 Poznań

tel. 618612276

e-mail: bskokowska@ump.edu.pl

Zakład Praktyki Pielęgniarskiej, Katedra Pielęgniarstwa, Wydział Nauk o Zdrowiu, Uniwersytet Medyczny im. K. Marcinkowskiego w Poznaniu 